\title{
Key factors influencing productivity of whole-tree ground-based felling equipment commonly used in the Pacific Northwest
}

\author{
Steffen Lahrsen, Omar Mologni, Juliana Magalhães, Stefano Grigolato, and Dominik Röser
}

\begin{abstract}
Around the globe, various types of forest machinery are employed to conduct fully mechanized ground-based timber harvesting. In the Pacific Northwest, the whole-tree harvesting method remains dominant. While machine-integrated sensors provide accurate productivity information in the cut-to-length harvesting method, productivity is more complicated to determine in whole-tree harvesting. This literature review compiles and analyses the existing evidence on productivity studies of feller-bunchers and feller-directors in a systematic manner and identifies the factors influencing machine productivity. The study indicates that most of the previous research was conducted in North America, particularly in Canada. It was also found that a considerable portion of the literature lacked statistical analysis. Piece size, slope, and silvicultural treatment were the most commonly studied productivity-influencing factors among the results. Although there is already a general understanding of the most important factors influencing the productivity of feller-bunchers and feller-directors, there is still a lack of accurate measurement and isolation of individual factors to facilitate accurate productivity prediction. Further research is needed for the development of systems that use integrated sensors capable of estimating machine productivity. Updated productivity models will optimize harvesting operations, identify bottlenecks, and allow for the development of best practices.
\end{abstract}

Key words: harvesting, efficiency, feller-buncher, feller-director, time study.

Résumé : Partout dans le monde, divers types de machines forestières sont utilisés pour effectuer la récolte de bois d'oeuvre au sol de manière entièrement mécanisée. Dans le Nord-Ouest du Pacifique, la méthode de récolte des arbres entiers demeure dominante. Bien que les capteurs intégrés aux machines fournissent une information précise sur la productivité dans la méthode de récolte de billes de longueur préétablie, il est plus difficile de déterminer la productivité dans la récolte des arbres entiers. La présente revue de la littérature compile et analyse les preuves existantes des études sur la productivité des abatteuses-empileuses et des abatteuses d'une manière systématique et identifie les facteurs influençant la productivité des machines. L'étude indique que la plupart des recherches antérieures ont été effectuées en Amérique du Nord, particulièrement au Canada. Nous avons également constaté qu'une partie considérable de la littérature manquait d'analyses statistiques. La taille des billes, les pentes et les traitements sylvicoles ont été les facteurs influençant la productivité qui ont été les plus couramment étudiés parmi les résultats. Bien qu'il existe déjà une compréhension générale des facteurs les plus importants influençant la productivité des abatteuses-empileuses et des abatteuses, il y a toujours un manque de mesures précises et d'isolement des facteurs individuels pour faciliter une prévision précise de la productivité. D’autres recherches sont requises pour le développement de systèmes utilisant des capteurs intégrés capables d'estimer la productivité des machines. Des modèles de productivité à jour optimiseront les opérations de récolte, identifieront les goulots d'étranglement et permettront le développement de pratiques exemplaires. [Traduit par la Rédaction]

Mots-clés : récolte, efficience, abatteuse-empileuse, abatteuse, étude par chronométrage.

\section{Introduction}

Forest operations have changed considerably over the recent decades. With the increasing importance of external factors such as global competition and safety regulations, this change is especially apparent within the degree of mechanization of timber harvesting (Spinelli and Magagnotti 2011; Parajuli et al. 2020). As a result, the use of forest machines has increased productivity, work safety, and accessibility to difficult terrain (Kellogg and Brink 1992; Axelsson 1998; Visser et al. 2014). Since the mechanized harvesting process is a complex operation that includes various combinations of expensive forestry machines, it is essential to understand the performance and interactions of these machines to ensure safe, economical, and competitive timber harvesting (She et al. 2018). The profitability of forest operations is fundamental to maintaining a healthy forest sector and improving the entire forest management process (Marchi et al. 2018). Various mechanized and semi-mechanized harvesting systems have been developed to implement silvicultural treatments and meet longterm objectives in differing conditions. These systems are historically categorized into ground-based, cable-based, and airship-based, depending on the primary transportation method used to move harvested logs from the cutblock to a road or landing (Heinimann 2004). In the felling phase of these systems, trees are cut either motor-manually by a chainsaw or by felling machines. Motor-manual felling, in combination with cable-based or airship-based primary

Received 28 September 2021. Accepted 8 December 2021.

S. Lahrsen, O. Mologni, J. Magalhães, and D. Röser. Department of Forest Resource Management, Faculty of Forestry, The University of British Columbia, Vancouver, BC V6T 1Z4, Canada.

S. Grigolato. Department of Land, Environment, Agriculture and Forestry TESAF, University of Padova, 35122 Padova, Veneto, Italy.

Corresponding author: Steffen Lahrsen (email: steffen.lahrsen@ubc.ca).

(c) 2022 The Author(s). Permission for reuse (free in most cases) can be obtained from copyright.com. 
transportation, is more commonly employed on challenging terrain that does not facilitate the use of ground-based felling machines (Kühmaier and Stampfer 2010). Mechanized felling requires the accessibility of felling machines to the stand and, for this reason, was traditionally limited to gentle terrain where ground-based primary transportation is employed. Recent interest in making operations on steep ground safer and more costefficient, however, led to the development and implementation of winch-assist technology that enables ground-based forestry machines to access very steep terrain (Visser and Stampfer 2015). Winch-assist harvesting systems allowed the development of fully mechanized steep slope harvesting operations, as well as the partial extension of mechanized felling in cable-based systems. Over the last decade, much effort has been made to investigate the production performances of these systems (Evanson and Amishev 2010; Amishev et al. 2017; Dyson and Strimbu 2018; Leslie and Koszman 2019a).

The term mechanized felling can account for different harvesting methods. Harvesting methods are defined by the form in which the harvested trees arrive at the landing. There are two key methods to cut and deliver the trees in mechanized harvesting: whole-tree and cut-to-length (Längin et al. 2010). Especially in the Pacific Northwest (British Columbia, Idaho, Oregon, Washington), the whole-tree method has a long history and has evolved to be the dominant harvesting method (MacDonald 1999; Gellerstedt and Dahlin 1999). In the whole-tree method, also referred to as fulltree method, the trees are cut and extracted in their full length to the landing, where they are processed (Soman et al. 2020). Alternately, cut-to-length harvesting accounts for the complete processing of the logs at the stump (MacDonald 1999). In mechanized felling systems for cut-to-length harvesting, a harvester, equipped with a processor head that grabs and fells the tree, delimbs the stem before bucking it into sorts. Two machines commonly employed in whole-tree mechanized harvesting are feller-bunchers and feller-directors. Feller-bunchers can be used for single stem or multi-tree harvesting and bunching. Feller-directors are less suitable for bunching, as their main task is to fell single trees. Carriers for both types of machines are categorized as either swing-to-tree or drive-to-tree machines and can vary greatly in their configuration (MacDonald 1999). Since the outset of mechanized harvesting, the most common machine configuration used for the felling in whole-tree harvesting operations in the Pacific Northwest has been tracked, swing-to-tree feller-bunchers with circular saw felling heads, hereinafter referred to as feller-bunchers (MacDonald 1999; Plamondon and Brais 2000). Feller-directors, equipped with a directional bar saw felling head, are becoming more important in winchassist steep slope harvesting in this area (Leslie and Koszman 2019a; Holzfeind et al. 2020).

The production performance of mechanized felling equipment can be expressed by "productivity" and "utilization". Productivity is defined as the "rate of product output per time unit for a given production system" (Björheden 1991), while utilization is commonly calculated as the rate of productive machine hours to scheduled machine hours. This rate represents the time in which the machine performs the intended function. While the utilization parameter allows for the adjustment of decision-making processes and supports logging cost analysis, productivity analyses help to identify the influence of process variables on the relationship between product output and time input. Time studies are used to determine productivity and utilization by analyzing the amount of time spent on individual work tasks. Thereby, the influence of different factors on the machine performance can be studied, and unnecessary time consumption can be avoided (Björheden 1991; Magagnotti et al. 2012; She et al. 2018). Productivity is often measured in volume or mass per delay-free productive machine hour $\left(\mathrm{PMH}_{0}\right)$ or productive machine hour including delays shorter than 15 min $\left(\mathrm{PMH}_{15}\right)$. The $\mathrm{PMH}_{0}$ can be converted into $\mathrm{PMH}_{15}$ by applying a correction factor that can be derived either from long-term time-study observations or from previous studies in similar conditions (Cadei et al. 2020). Productivity rates are commonly derived from cycle time, the number of logs felled per cycle, and the average volume per log (e.g., Alam et al. 2013; Strandgard et al. 2015; Han et al. 2018).

Productivity research is particularly important in the Pacific Northwest, where the whole-tree harvesting method remains dominant. With the equipment commonly used for felling and primary transport (feller-buncher and grapple skidder), it is challenging to achieve accurate productivity estimation. Unlike harvester and processor heads, these machines are not equipped with sensors that provide real-time productivity information (Gingras and Charette 2017). Up to now, the true harvest volume remains unknown until the felled logs are processed at the landing. Volume and location information of log bunches could enhance the performance of primary transportation. To improve the overall productivity of whole-tree harvesting operations, existing productivity models need to be updated or evolved to support connectivity and data collection technologies. The forest industry strongly needs research to support decision-making processes through the development of new productivity models, algorithms, and benchmarking tools for machines involved in the whole-tree harvesting method.

This review aims to identify all the significant factors that influence the productivity of feller-bunchers and feller-directors. The review will highlight the abundance and global distribution of evidence on the performance of these two felling machine types and thereby identify the most important factors that must be taken into consideration for varying harvesting scenarios. It further enables drawing a conclusion of which factors need to be studied to increase understanding to improve the harvesting productivity prediction in the Pacific Northwest.

\section{Materials and methods}

This review paper was conducted using a systematic approach. The methodology included preparation, search, screening, data extraction, and analysis stages.

\section{Search for articles}

The search for literature was carried out on the following bibliographic databases and search engines, with subscriptions of The University of British Columbia and the University of Padova.

- Web of Science core collection (WOS)

- CAB Abstracts, Forest Science Database - CABI (CAB)

- Scopus (SCP)

- PubAg, USDA - United States Department of Agriculture (PUB)

- Treesearch, USDA, U.S. Forest Service (TRS)

- Global Forest Information Service (GFIS)

- Agricultural Science and Technology Information (AGRIS)

- IUFRO on-line literature database (IUFRO)

A scoping exercise was conducted on WOS, CAB, and PUB. First, a single keyword search and a result analysis were applied. In the next phase, keywords were combined into search strings. Different search strings were tested to cover a broad, yet specific scope. After a substantial number of hits was obtained, two refined search strings were used to find evidence on WOS, SCP, CAB, and AGRIS:

\section{Search string 1}

((Forest*) OR (“Forest Operations”) OR (“Forest Utilization”) OR ("Forest Management”) OR (Silviculture) OR (Logging) OR (Harvesting)) AND ((Machine) OR (Mechanized) OR (Mechanised)) AND (("Whole tree") OR (Whole-tree) OR ("Full tree”) OR (Full-tree) OR ("Tree length") OR (Tree-length)) AND ((Productivity) OR (Efficiency) OR ("Time study") OR ("Time and motion") OR ("Work study") OR ("Work method study") OR (“Observational study”) OR 
(“Time and output study”)) NOT ((“Hand falling”) OR (“Hand felling”) OR (“Motor-manual”))

\section{Search string 2}

((Feller-buncher) OR (Feller buncher) OR (Feller-director) OR (Feller director)) AND ((Productivity) OR (Efficiency) OR ("Time study") OR ("Time and motion study") OR ("Work study") OR ("Work method study") OR ("Observational study") OR ("Time and output study"))

Search string 1 addressed a broad machine-unspecific scope that included productivity studies in whole-tree harvesting operations, where "tree length" is sometimes used synonymously (e.g., Thompson 2003; Visser and Stampfer 2015; Pan and McDonald 2019). Search string 2 targeted productivity studies in a machinespecific scope. For the remaining databases (PUB, TRS, GFIS, IUFRO), the search strings had to be adjusted for compatibility with the search tools.

The web-based search engine Google Scholar (GOS) has proven to be a good resource for gray literature (Haddaway et al. 2015) and was used to obtain additional results. The output of results from each query is user-dependent and can vary any time a search with identical search strings is conducted. To extract the results aggregated from Google Scholar as citations, the software Publish or Perish $\odot$ version 7.27.2949.7581 was used (Harzing 2007).

Finally, two relevant organizational libraries were included in the search for evidence:

\section{- Forest Growers Research (FGR), New Zealand \\ - FPInnovations (FPI), Canada}

FGR and FPI are research institutions that publish technical reports internally and publicly. Both are relevant sources for grey literature. Since neither of these web-page-implemented search engines accepts Boolean operators such as "OR", "NOT", or "AND", or truncations, the search strings were not used. Instead, two searches were conducted on each of the organizational websites using the search terms "feller buncher" and "feller director".

The reference management software Mendeley@ Desktop version 1.19.8 was used to assemble a library of the search results (Elsevier 2021). All of the results from the sources mentioned above were combined, and the software-integrated tool "duplicate removal" was applied.

\section{Screening}

After duplicates were removed, the Mendeley@ library was exported, and the web-based systematic review managing software Covidence $\odot$ was used for the title and abstract screening process (Covidence 2021). A full-text screening followed. Results that passed the first screening stage were retrieved online, to the extent possible. The screening process was conducted by the main author only, which made a consistency check unnecessary.

At all stages of the screening process, the following inclusion and exclusion criteria were applied:

- Eligible harvesting systems: whole-tree

- Exclude: cut to length (unless studied in comparison to wholetree harvesting)

- Eligible influencing factors: any factor that influences the studied machine productivity

- Eligible silvicultural treatments: clear-cutting, shelterwoodcutting, single-selective-cutting, seed-tree-cutting, patch-cutting, retention-cutting, commercial thinning

- Exclude: pre-commercial thinning, coppice, short-rotation plantation
- Eligible study approaches: elemental time and motion studies, machine simulator studies, shift-level studies

- Eligible outcomes: volume per time unit, time per cycle, time per volume unit

- Eligible study types: peer-reviewed journal articles, technical reports, doctoral dissertations, working papers, conference proceedings

- Exclude: review articles

- Eligible languages: English

- Eligible machine types: tracked swing-to-tree machines equipped with a circular saw feller-buncher head or feller-director head

- Exclude: rubber tire or drive-to-tree machines and processor heads (unless studied in comparison to tracked fellerbunchers or feller-directors)

The authors decided to exclude short-rotation plantation and coppice harvesting studies since they involve the management of woody biomass on agricultural land, which cannot be compared to traditional forest utilization (Faasch and Patenaude 2012). Productivity studies on harvesting systems do not always specify the involved machines in their title or abstract. Therefore, results that remained unclear in their content were included in the fulltext screening. After the full-text screening, the included results were compiled for data extraction.

\section{Data extraction}

Of the included results, the information shown in Table 1 was extracted and collected in a Microsoft ${ }^{\circledR}$ Excel spreadsheet, if available.

The meta-data was extracted by only the main author to maintain consistency. If needed, reported productivity rates, stem volumes, and diameter at breast height (DBH) were converted from the imperial unit system (i.e., inches, feet, acre) into metric units. Board feet were converted into cubic metres $\left(\mathrm{m}^{3}\right)$ according to a fixed conversion factor of 0.0023597 (Rowlett 2018). Productivity rates reported in mass were not converted into volume due to the lack of species and region-specific conversion rates. Whenever a result contained more than one study, each was recorded as an individual entry in the database.

\section{Search results}

The search resulted in a total of 4574 hits (1335 records found on bibliographic databases, 3239 from search engines and online libraries). After the duplicate removal, 2960 results remained for the title and abstract screening (Fig. 1). During this process, 2215 results were excluded. Of the remaining 745 results, 523 were retrieved in full text. After all titles and abstracts were filtered for the English language during the full-text screening process, an additional 62 results were excluded because of this language criterion. Out of the full-text reviewed results, 75 results that included studies of fellerbunchers (67) or feller-directors (8) were selected for data extraction. Figure 1 displays the progress from search to data extraction.

The selected results consisted of 19 peer-reviewed journal articles, six conference proceedings, one book chapter, and 49 technical reports. Of all results, 34 provided statistical analysis (e.g., ANOVA, Kruskal-Wallis test, linear regression). These included 17 of the peer-reviewed articles, four conference proceedings, one book chapter, and 12 technical reports

The geographical distribution of the results was relatively clustered. Most of the evidence on feller-buncher productivity was gathered in North America (43 results Canadian research, 18 results US American research). Australia was counted in seven results as country of origin, three results were obtained from New Zealand, two from Italy, and one from Turkey. This distribution can be explained by the simple fact that most of the results were retrieved as technical reports from FPInnovations, which is a Canadian-based research institution. Out of the results that included research from Canada and the USA, 18 studies were 
Table 1. Categories of extracted information and referring units.

\begin{tabular}{ll}
\hline Information & Extracted unit \\
\hline Bibliographic information & $\begin{array}{c}\text { Source database, title, keywords, abstract, author, journal, year, language, } \\
\text { publication type, DOI } \\
\text { Country name }\end{array}$ \\
$\begin{array}{l}\text { Country } \\
\text { Location }\end{array}$ & $\begin{array}{c}\text { Monocultural coniferous plantation, monocultural deciduous plantation, } \\
\text { Forest type }\end{array}$ \\
mixed-coniferous, mixed-deciduous \\
Stand density & Trees/ha \\
Ground slope & Percent \\
Average tree size, e.g., DBH, volume, etc. (standing trees & cm, m ${ }^{3}$ \\
and (or) harvested logs, as reported) & \\
Method of determining tree size & Sample-based average, cruise data, all trees measured \\
Silvicultural treatment & Clear-cutting, shelterwood-cutting, single-selective-cutting, seed-tree-cutting, \\
& patch-cutting, retention-cutting, commercial thinning \\
Variables that influence the productivity & Name \\
Effect on productivity & Enhancing, diminishing, no significant effect \\
Work-study level & Elemental level, shift level \\
Productivity model & Equation \\
Productivity rate & Rate of product output per time unit as reported in study \\
Statistical analysis & Statistical method (e.g., regression, ANOVA, $t$ test) \\
Felling head model & Name \\
Machine model & Name \\
Machine mass & kg \\
Engine power & kW \\
\hline
\end{tabular}

Fig. 1. Literature review flow chart illustrating the number of results during different stages of the work process (adapted from Moher et al. 2009). The numbers indicate the number of results remaining after each step of the work process.

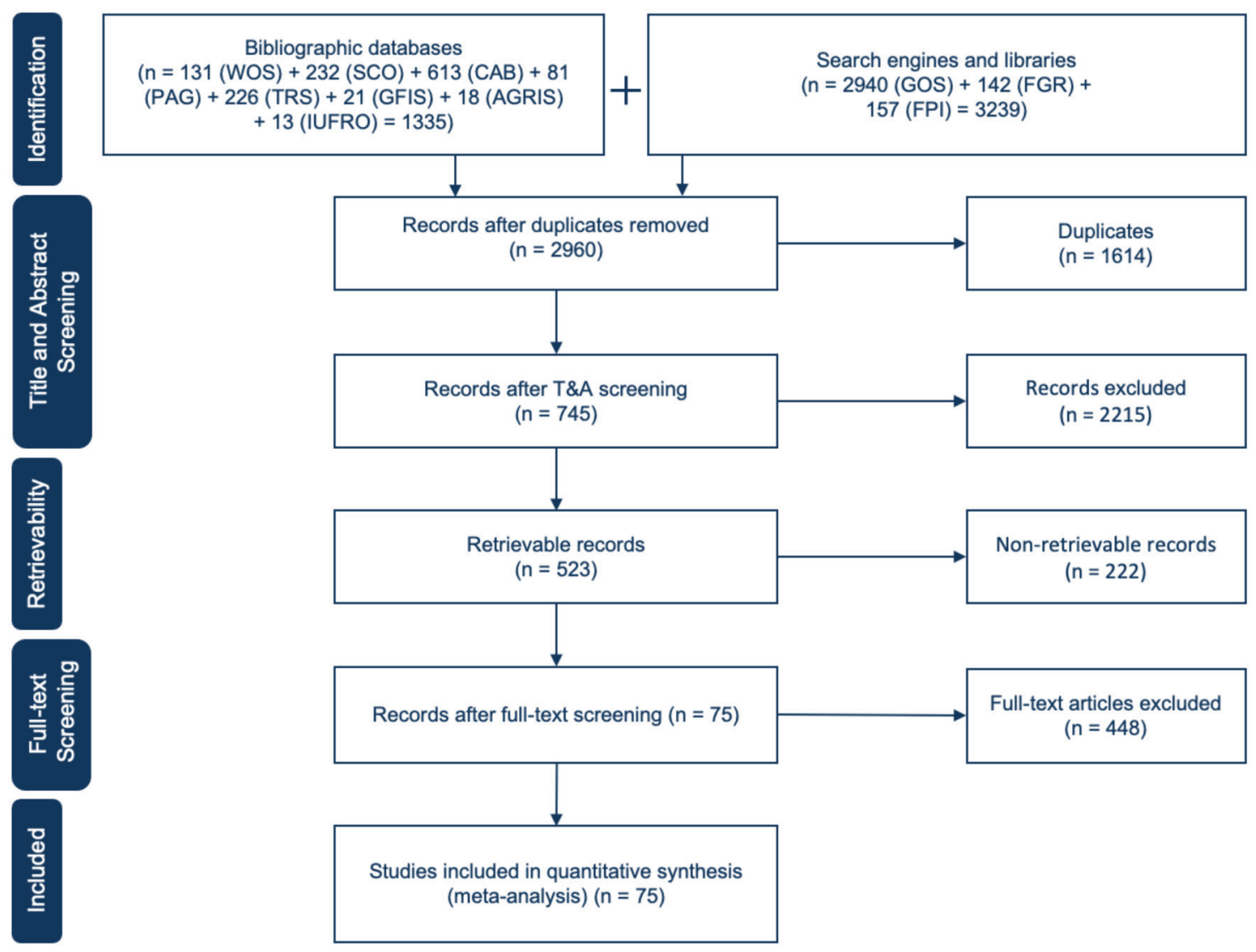


Table 2. Factors that influenced feller-buncher and feller-director productivity mentioned in the result, categorized into site- and standrelated, and operation-related, ordered by counts.

\begin{tabular}{lll}
\hline & Count \\
\cline { 2 - 3 } Productivity influencing factor & Feller-buncher & Feller-director \\
\hline Site- and stand-related & & \\
Piece size & 27 & 3 \\
Ground slope & 7 & 2 \\
Obstructions & 5 & 3 \\
Species composition & 6 & - \\
Stand density & 3 & 2 \\
Operation-related & & \\
Silvicultural treatment & 14 & - \\
Harvesting intensity & 8 & - \\
Sorting & 6 & - \\
Operator skill & 5 & - \\
Trail layout & 4 & - \\
Trees per cycle & 4 & 1 \\
Machine performance & 2 & 2 \\
Anchor machine behavior & - & \\
(only winch-assist) & & \\
\hline
\end{tabular}

conducted in the Pacific Northwest. Silversides and Sundberg (2013) did not specify the location of research.

In this study, search results were not excluded based on their publication date. Deliberately, no exclusion criterion was applied regarding the age of a study since there was no abrupt technological advancement in the development of the studied machines. The technology of these machines has been constantly evolving. Another reason for not applying an exclusion criterion is that outdated technology is still being used for timber harvesting in BC. Nevertheless, only three studies were published before 1995 (McMorland 1985; Richardson 1989; Williams 1990).

\section{Productivity influencing factors}

Productivity rates for feller-bunchers and feller-directors were reported in 60 and eight results, respectively. The remaining results reported productivity influencing factors without providing productivity rates. Out of the results that measured fellerbuncher productivity rates in volume/PMH (52), 90\% reported productivity within a range of 9.6-150 $\mathrm{m}^{3} / \mathrm{PMH}$. Exceeding this range, productivity rates as high as $291 \mathrm{~m}^{3} / \mathrm{PMH}$ were reported in five results (Andersson and Jukes 1995; Andersson 1997; Adebayo et al. 2007; Rittich 2017a; Soman et al. 2020). Feller-buncher productivity rates reported in mass/PMH raged from 13 to 74.2 ovendry tonnes/PMH. The results that included feller-director studies reported a range of 7.3-88 $\mathrm{m}^{3} / \mathrm{PMH}$. This literature review, however, does not categorize or compare productivity rates, as the studies discussed were conducted in variable terrain, and for most, a combination of factors influenced the reported productivity. To directly compare individual factors among the results of several research studies, these factors need to be isolated. It is therefore essential to investigate individual factors in a controlled environment, which can be provided by machine simulators, for example (Ovaskainen et al. 2011).

Factors reported to have affected productivity were categorized into site- and stand-related and operation-related variables. Multiple factors directly related to each other were aggregated in groups. The relevance of factors and groups of factors was determined by how often they were mentioned in the results. With 59 total counts, site- and stand-related factors were the most studied factors, while operation-related factors were studied in 49 of the results (Table 2).
Fig. 2. Counts per diameter at breast height (DBH) class for fellerbuncher (FB) and feller-director (FD) studies.

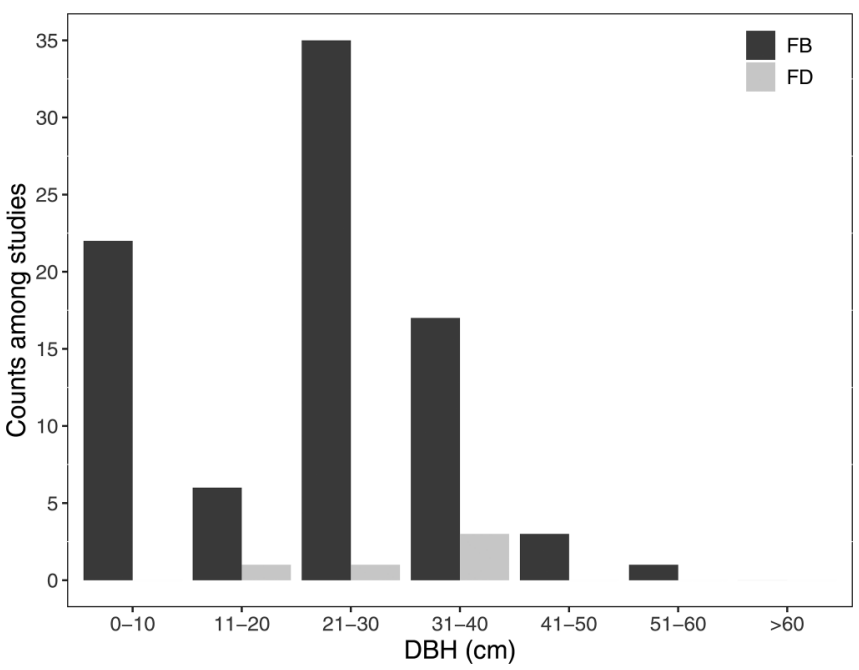

Among all, eight of the results that investigated feller-buncher operations (McMorland 1985; Han and Renzie 2001; Akay et al. 2004; Harrill and Han 2012; Spinelli et al. 2013, 2014; Dyson and Boswell 2016; Roy and Rittich 2017a) presented productivity rates without mentioning any influencing factors. In cases of multiple publications referring to the same results (Amishev and Evanson 2010; Evanson and Amishev 2010; Alam et al. 2013, 2014), the mentioned outcomes were only counted once.

\section{Site- and stand-related factors}

\section{Piece size}

Piece size is defined here as a group of factors referring to the volume of standing trees, volume of harvested logs, and standing tree diameters $(\mathrm{DBH}, \mathrm{cm})$. A value for piece size was reported in 60 results. However, not all of the results investigated its effect on productivity. In most of the results, an average tree or merchantable stem volume derived from cruise data, samples, or an average log size derived from data obtained during the processing of the logs, was used to determine productivity rates. In 20 of the results, it was not defined how productivity rates were obtained. Instead of using an average tree size achieved from cruise data or field samples to calculate productivity, Alam et al. (2013) improved the methodology by measuring each stem prior to felling. To get a better understanding of the distribution of studies across different piece sizes, the results were grouped into size classes according to the average piece size reported. Since piece size was reported differently among the results, three categories were created to classify the studies. Several results reported multiple studies, each with different piece size classes. Every study with a reported piece size equals one count. Of the fellerbuncher studies that reported an average $\mathrm{DBH}, 79 \%$ were conducted in a range of 0-30 $\mathrm{cm}$ (Fig. 2). Of the feller-buncher studies that reported an average standing tree volume, $63 \%$ were conducted in stands with up to $0.60 \mathrm{~m}^{3} /$ tree (Fig. 3). Of the fellerbuncher studies that reported an average harvested stem volume, $69 \%$ were conducted in stands with up to $0.60 \mathrm{~m}^{3} / \mathrm{stem}$ (Fig. 4). Reported feller-director studies were conducted in stands with average DBHs ranging from 11 to $40 \mathrm{~cm}$ (Fig. 2). Of the feller-director studies that reported an average standing tree or harvest stem volume, $57 \%$ were conducted in stands with an average standing tree volume greater than $0.81 \mathrm{~m}^{3} /$ tree (Fig. 3) and $80 \%$ in operations with an average harvested stem volume greater than $1.01 \mathrm{~m}^{3} / \mathrm{stem}$ (Fig. 4) respectively. The distribution of counts among the DBH, 
Fig. 3. Counts per tree volume class for feller-buncher (FB) and feller-director (FD) studies.

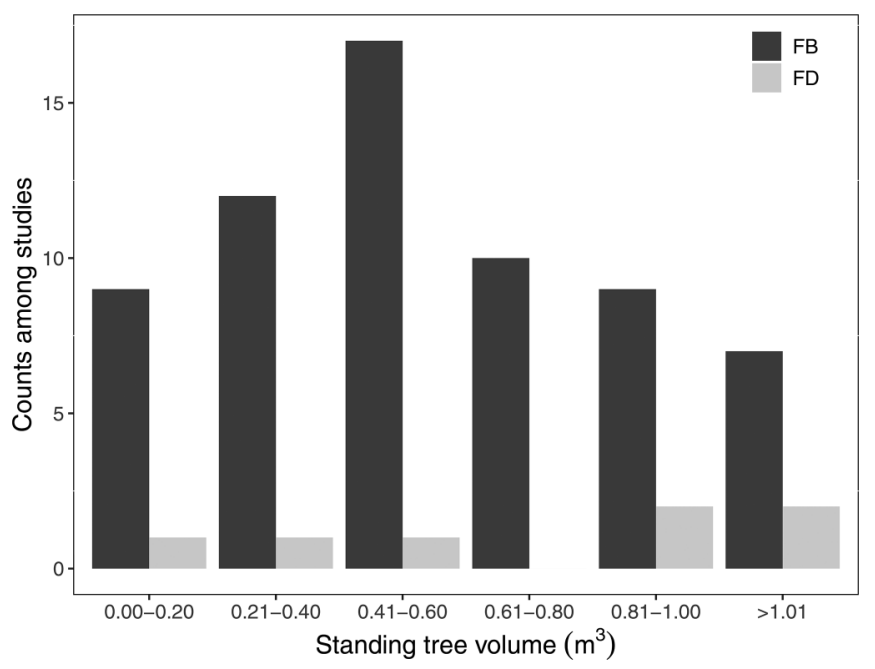

Fig. 4. Counts per harvested stem volume class for feller-buncher (FB) and feller-director (FD) studies.

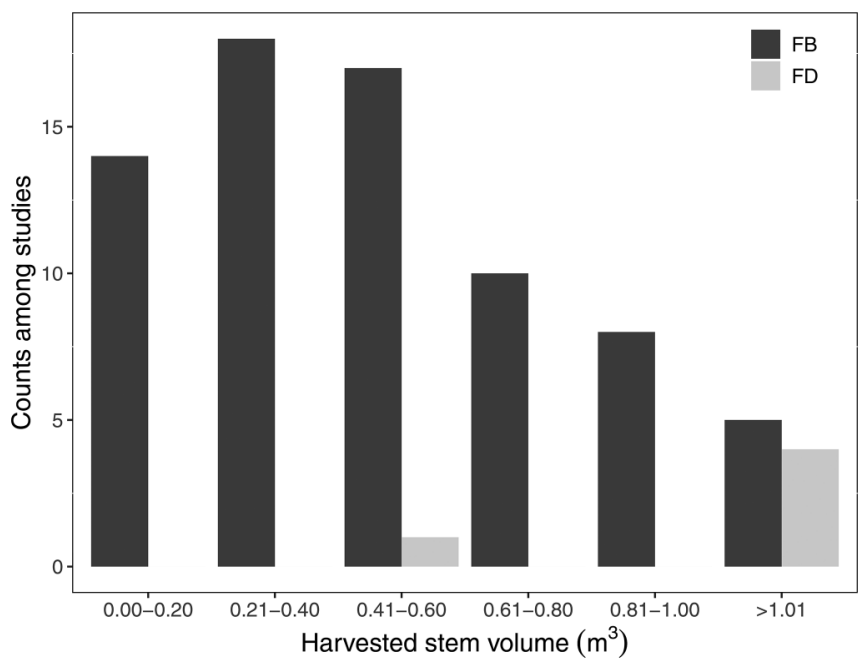

tree volume, and harvested stem volume indicates a lack of studies in the largest classes, especially for feller-bunchers, which could be explained by a maximum felling-head diameter and more complicated felling techniques for larger diameter trees (Strandgard and Mitchell 2010).

Nevertheless, piece size was by far the most studied factor influencing feller-buncher and feller-director productivity (30 counts in total). The harvested stem size (volume, $\mathrm{m}^{3}$ ) was mentioned in 12 results (Meek 1997, 2006; Phillips 1997; McMorland 2002; Hillman 2003, 2004, 2005; Girard 2009; Visser 2009; Roy and Rittich 2017b; Amishev and Dyson 2018; Dyson and Strimbu 2018), tree size (volume, $\mathrm{m}^{3}$ ) was mentioned in nine results (Richardson 1989; Andersson and Jukes 1995; Andersson and Evans 1996; Andersson 1997; Strandgard and Mitchell 2010; Lepage and Meek 2011; Alam et al. 2013; Silversides and Sundberg 2013; Ghaffariyan 2019), and trees size (DBH, cm) was mentioned eight times among the results (Andersson and Jukes 1995; Andersson 1997; Long et al. 2002; Adebayo et al. 2007; Ghaffariyan and Acuna 2012; Ghaffariyan et al. 2012; Hiesl et al. 2015; Soman et al. 2019). Long et al. (2002) were the only ones that mentioned merchantable tree height $(\mathrm{m})$ as a significant productivity influencing factor.
Fig. 5. Counts per slope class for feller-buncher (FB) and feller-director (FD) studies.

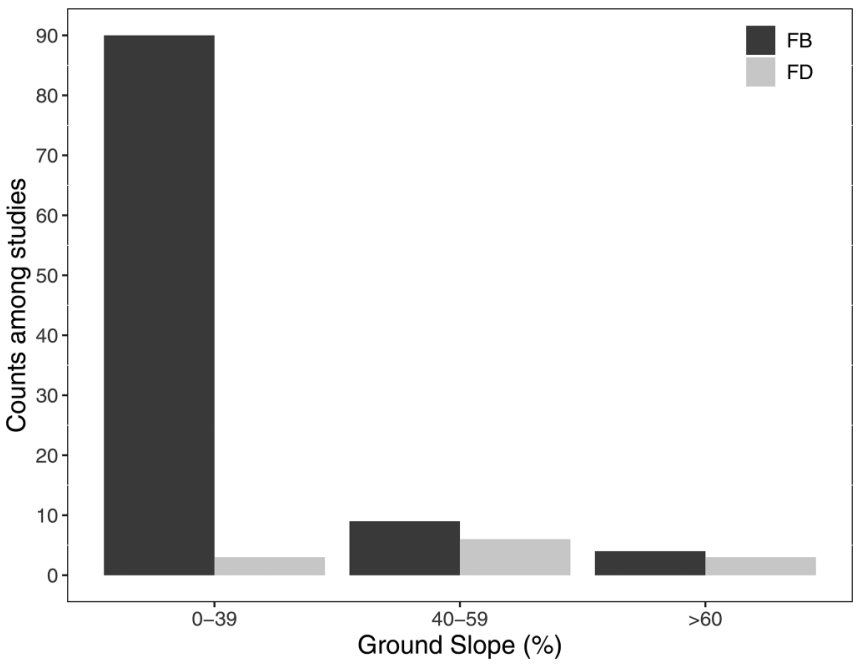

Among all the results examining piece size, there is unanimity on a positive correlation between size (tree or stem volume, height, DBH) and machine productivity. These observations are in accordance with the "piece size law", which states the mechanical harvesting productivity increases at a decreasing rate with an increasing piece size (Visser 2009). Richardson (1989) found that standing tree volume was the most important factor influencing not only the feller-buncher but also the feller-director productivity. Andersson and Evans (1996) reported that $79 \%$ of the variation in the productivity observed in elemental time and motion studies was explained by differences in the average volume per tree. Further, Meek (1997) stated that the harvested stem volume affects the productivity of mechanized harvesting more than the productivity of motor-manual harvesting. The study showed that an increasing stem volume decreased the travel and bunching time, as it was more challenging to accumulate enough small trees to an optimum bunch size for skidding. Strandgard and Mitchell (2010) reported a drop in the rate of productivity increase with increasing stem size, assuming that the flattening of the increase rate could be explained by a smaller number of stems per accumulation and the difficulty of handling stems of larger size. According to Visser (2009), in contrast to the piece size law, there is a point at which the productivity of harvesting machines starts to decrease with increasing piece size. This machine-dependent "sweet-spot" projects the optimum piece size to achieve maximum productivity. Visser (2009) plotted the productivity rate over piece size for various harvesting operations with feller-directors (mass 25-30 tonnes) on gentle ground using an exponential regression and observed that the optimum piece size was $3.4 \mathrm{~m}^{3} / \mathrm{stem}$. His study was the only one to investigate optimum piece size for feller-directors.

\section{Ground slope}

The degree of ground slope can affect a felling machine's ability to travel. In 49 results, the ground slope, expressed as the slope percent, was mentioned for individual study sites. The average slope percent among the results was categorized into three slope classes based on travel abilities of conventional, specialized, and winch-assist machines (plain to moderate slope 0\%$39 \%$; moderate steep slope $40 \%-59 \%$; steep slope $>60 \%$ ) (Fig. 5). Most of the feller-buncher studies (92\%) were conducted on ground slopes from $0 \%$ to $39 \%$. The distribution of feller-director studies is relatively equal among the three classes. 
Ground slope was the second most studied factor in the category of site- and stand-related factors (nine counts). The degree to which ground slope affects machine productivity varies between the results. A decreasing effect was observed on moderate steep (40\%-59\%) and steep slopes (>60\%) (McMorland 2002, 2008; Kosicki and Dyson 2003; Alam et al. 2013; Amishev et al. 2017; Amishev and Dyson 2018; Dyson and Strimbu 2018). Plain to moderate slopes (0\%-39\%) did not seem to affect the productivity of feller-bunchers (Watson et al. 1995; Hillman 2001; Alam et al. 2013).

It is expected that the variable slope was difficult to isolate for most of the studies, which explains the variations in degree of influence reported for slope (Alam et al. 2013). To isolate the effect of slope better, Alam et al. (2013) analyzed the traveling and felling time of a feller-buncher with a self-leveling cab based on digital terrain model derived from LiDAR data. The study was able to show an increase in time consumption for the two cycle elements, traveling and felling, with increasing slope percent. One of the explanations for this increase was a different technique used by the operator for felling and bunching on steeper slopes. The operator felled the trees while moving uphill on a plain to moderate slope, which is more comfortable for operators and increases productivity. On moderate steep slopes, the operator felled trees while moving downhill and bunched them while moving uphill again. A considerable amount of time was spent dragging the felled trees into areas where they were easy to extract.

Different winch-assist systems that included feller-directors were investigated as well. Dyson and Strimbu (2018) and Leslie and Koszman $(2019 a, 2019 b)$ studied the operations of a fellerdirectors assisted by a winch mounted on a remotely operated bulldozer (ROB). Evanson and Amishev (2010) studied a prototype feller-director with a winch mounted to the carrier. Amishev et al. (2017) studied a winch-assist system in which an excavatorbased anchor machine was equipped with two winches and two parallel cables. All the mentioned results report the feasibility of these systems in moderate steep slopes to steep slopes. However, only Dyson and Strimbu (2018) stated a decrease in productivity on steep pitches with slopes percent between $80 \%$ and $85 \%$. Only Amishev and Dyson (2018) and Leslie and Koszman (2019b) studied winch-assist harvesting systems that included feller-bunchers.

\section{Obstructions and stand homogeneity}

Site- and stand-related factors that potentially influence the machines' workflow or ability to travel were compiled in this section. Less-favorable terrain conditions such as uneven ground, ditches, boulders, small valleys, short, abrupt slopes, snow, and downed trees are examples of these obstructions (Richardson 1989; Meek 1997; Dyson and Strimbu 2018). In six of these results, productivity decreased with an increasing level of obstructions and stand heterogeneity. Gingras and Godin (1996), Kim (2017), and Han et al. (2018) reported a decrease in feller-buncher productivity in the harvesting of blowdown timber compared to conventional operations. In Han et al. (2018), the feller-buncher's cycle time increased by up to $56 \%$ when handling downed trees. The study investigated the effect of beetle-infested stands on productivity and concluded that the number of downed trees increases with the time passed after a beetle infestation due to windthrow, affecting the productivity of feller-bunchers. McMorland (2008) reported a non-significant effect on productivity of stand conditions after beetle infestations. However, no information on the ratio of downed trees in the studied stands was provided. Meek (1997) reported a reduction in productivity of a feller-buncher operating on relatively flat but unfavorable terrain when compared to operations on a moderate steep but even slope. The absence of ground obstacles appeared to favor the feller-buncher's movement and thereby decreased moving time, leading to an increase in productivity. Terrain roughness was observed to have
Fig. 6. Counts per species composition type for feller-buncher (FB) and feller-director (FD) studies. Mix-C, conifer-dominated stands containing mixed species (conifers or broadleaf trees); Mix-B, stands dominated by broadleaf trees. Stands in which only one tree species (conifer or broadleaf trees) occurred were considered monocultures (Mono-C; Mono-B).

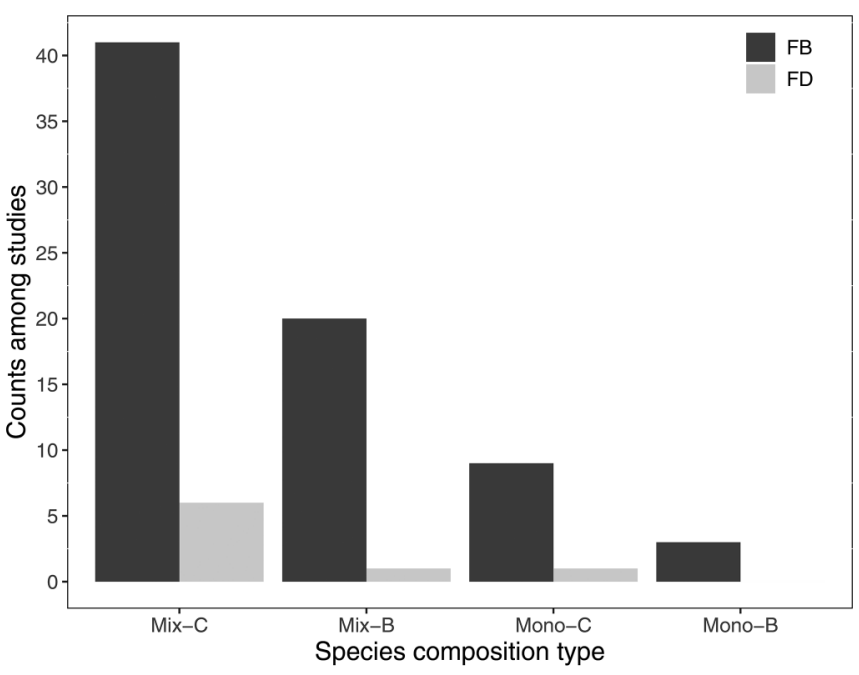

a decreasing effect on productivity by Richardson (1989), as obstacles that could not be climbed by the carrier increased the traveling time. Dyson and Strimbu (2018) reported that obstructions such as slash left on the ground from earlier felling operations had to be moved by the feller-director, which increased the traveling time.

Only a small number of results reported snow cover during the studied feller-buncher operations. The direct effect of snow cover on machine productivity was not studied in any of these results. However, Han and Renzie (2001) noticed that less than $50 \mathrm{~cm}$ snow cover did not influence the feller-buncher's ability to cut the stems at a low position, close to the ground. On the contrary, Nishio (2010) reported a negative effect of snow cover, which decreased the productivity of the entire whole-tree harvesting operation, without making observations for individual machines. In a study by Leslie and Koszman (2019a), the machine operator reported a decrease in traction while operating on snow. The operator further noticed that ice built up within the felling head which can potentially lead to mechanical issues due to a decrease in flexibility of hydraulic hoses.

\section{Species composition}

Previous studies have shown that tree characteristics affect the felling time of harvesting machines. For example, differences in the pattern of branch and crown growth might explain differences in the productivity of feller-bunchers when harvesting coniferous and deciduous tree species (Dodson et al. 2006). The individual studies in the results of this review were categorized into four different types of species compositions (mixed-conifer, mixed-broadleaf, monoculture-conifer, monoculture-broadleaf) to highlight the abundance of studies in coniferous dominated stands (Fig. 6). The most commonly mentioned species composition types in the results are mixed-conifer (58\%) and mixed-broadleaf (26\%). Operations in monoculture stands were studied less often (mono-conifers $=12 \%$; mono-broadleaf $=4 \%$ ). Species distribution was not provided in many of the results. A stand was considered mixed-species if there were more than one species listed. The number of monocultural or mixed-coniferous stands among the studies in the results might be explained by the geographical 
distribution of the results. Most of the studies were conducted in areas where coniferous species are dominant.

The effect of species composition was mentioned in six results with differences in its impact on feller-buncher productivity. Four studies reported no significant effect of species composition on productivity (Williams 1990; McMorland 2008; Hiesl et al. 2015; Kizha and Han 2016). Two studies reported an effect of species composition that either increased (Hillman 2005) or decreased productivity (Soman et al. 2020). Soman et al. (2020) reported an increasing effect of the variable "species" on delay-free cycle time in a hybrid tree length operation. It was assumed in the study that the contrast in species characteristics between hardwood and softwood species affected the felling time. Hillman (2005) observed higher productivity for harvesting white birch (Betula papyrifera Marshall) when compared to harvesting coniferous trees of the same stem volume in the same stand. This difference was explained by the different dispersion of the two species over the cut block that his studies were conducted in.

\section{Density}

Stand density and related factors (basal area, volume/ha), studied in five results, were grouped in this section. Three of the five results reported an increase in productivity with increasing stand density for both feller-bunchers (Andersson and Evans 1996; Long et al. 2002) and feller-directors (Richardson 1989). The remaining two studies reported no significant effect of stand density (Hiesl et al. 2015) or the basal area per hectare on feller-buncher productivity (Meek 2006). Increasing productivity has been linked by Andersson and Evans (1996) to an exponential increase in travel time with decreasing stand density. Hence, the effect of density was noticeable to a higher degree in less dense stands. Similarly, Richardson (1989) and Long et al. (2002) reported an increase of felling time with increasing distance between merchantable stems. Silversides and Sundberg (2013) support these findings with productivity equations that show an increase of productivity per PMH with an increase of volume per hectare. In contrast to this, Hiesl et al. (2015) found that neither stand density nor the basal area per hectare significantly affected feller-buncher productivity. A linear mixed-effects model did not show explanatory differences in stands with unusually high densities, varying from 3211 to 5496 trees per hectare, in a non-precommercial-thinned stand (Hiesl et al. 2015). Similarly, Meek (2006) found no significant relationship between any measured operating conditions, including the stand density.

\section{Operation-related factors}

\section{Silvicultural treatment and site preparation}

Among the operation-related factors, the effect of different silvicultural treatments on feller-buncher productivity was studied the most. Compared to clearcuts, a decrease in productivity has been observed in single-tree or group selection cuts (Meek and Légère 1998; Riopel et al. 2000; McMorland 2002; Hillman 2003; Sambo 2003; Phillips 2004; Sauder and MacIsaac 2004; Girard 2009; Vitorelo et al. 2011; Meek 2013; Botard et al. 2015), while an increase in productivity was only found in one single-tree selection cut study (Nishio 2010). However, no significant differences in productivity were found in partial cuts (Hartley and Han 2007; Phillips 2010). None of the results studied the effect of different silvicultural treatments on feller-director productivity.

It was shown that the work cycle time is directly affected by the machine's maneuverability, which can be restricted in silvicultural treatments that protect individual stems (Riopel et al. 2000; Hillman 2003; Phillips 2004). The precaution with which the operators must maneuver their machines to avoid damaging residual trees increases travel time and thereby reduces the machine's productivity (Soman et al. 2020). In Soman et al. (2019), the differences in machine productivity between a clearcut and a selection cut operation decreased with an increasing mean harvested stem volume. This is supported by the findings of McMorland (2002), who showed that selection cut felling operations had a lower productivity when compared to clearcut operations under similar stand conditions (in terms of DBH and slope percent). Lowered productivity rates resulting from longer travel times in selection cuts were also shown by Meek and Légère (1998), Sambo (2003), Sauder and MacIsaac (2004), and Meek (2013). Nishio (2010) observed higher productivity in a selection cut treatment compared to a clearcut operation. However, the average stem size was much higher in the stand chosen for the selection cut treatment, which most likely explains these contradicting findings. Phillips (2010) observed increased cycle times in single-tree selection cuts when compared to both clearcut and group-selection operations. Due to insufficient data, the study did not find statistical significance in these differences.

To better understand the effect of site preparation on the cycle time of a feller-buncher, Cormier (2002) studied spot scarification during felling. A prototype circular saw felling head was equipped with a toothed, hinged steel plate. The operator dragged the felling head along the ground while retracting the boom. On average, $14 \%$ of the cycle time was spent on this additional work element. When compared to conventional operations, the productivity of the machine decreased with higher degrees of spot densities, especially in stands with low harvest volumes.

\section{Harvesting intensity}

The harvesting intensity is very closely related to both the applied silvicultural treatment and the stand density. The intensity with which trees are felled can vary considerably between different treatments. In this study, the level of retention (Mcnamara et al. 1999; Phillips 2004), removal volume (Hiesl et al. 2015), distance between harvested trees (Long et al. 2002; Girard 2009; Vitorelo et al. 2011; Soman et al. 2020), and basal area harvested (Meek 2006) were aggregated as harvesting-intensity-related factors. Girard (2009) stated that the productivity of feller-bunchers was higher in a clearcut than in a selection cut at equal harvested stem volumes. This was explained by an increase in travel time between trees to be felled. Similar to the effect of stand density in a clearcut operation, productivity decreases with a greater distance between selected trees. Soman et al. (2020) found that felling productivity was inversely proportional to the distance between harvested trees. Several studies reported decreasing productivity with an increasing level of retention in the selection cut treatments, which can also be explained by an increase in maneuver and travel time (Mcnamara et al. 1999; Phillips 2004; Meek 2013). On the contrary, Meek (2006) reported no significant effect of the harvested basal area on productivity in a comparison of several single-tree selection cuts. Hiesl et al. (2015) compared thinning operations with different removal intensities. The study concluded that removed volume per hectare did not significantly influence the feller-buncher productivity. Rather, it was suggested that advantages in technology, highly skilled operators, and marking of crop trees prior to harvesting influenced the results.

\section{Sorting}

In a conventional whole-tree system, the felled trees are extracted to the landing area, where they are processed and sorted by a processor. The six results that included studies of alternative sorting approaches and their effect on machine productivity are discussed in this section. Gingras and Godin (2001) compared conventional sorting at the landing with pre-sorting by species at the stump. The study observed that feller-buncher productivity was decreased by $9 \%$ in a harvesting operation in which the felled stems were sorted at the stump. This was explained by an increase in travel time between the stump and separate bunches 
for different species. In addition, the number of stems accumulated per cycle was reduced when separating species due to the even distribution of the species over the area. These results were supported by earlier studies that also evaluated the effect of sorting at the stump (Gingras and Godin 1996; Gingras and Soucy 1999). McMorland (2008) and Conrad et al. (2013) studied the effect of sorting multiple products on productivity. McMorland (2008) stated that there is a significant decrease in productivity when sorting one product compared to two. In contrast, no difference was shown between two compared to three products. Meek (1997) studied a method of partially delimbing and sorting deciduous trees in partial cuts. The additional element in the feller-buncher's work cycle decreased its productivity when compared to operations in which the delimbing was done motormanually. Kizha and Han (2016) did not observe a significant effect of pre-sorting the felled stems on the feller-buncher's productivity.

\section{Operator skill}

Operator skill has been shown to influence productivity, as the training of the machine operator affects the way the machine is maneuvered (Richardson 1989; Dyson and Strimbu 2018). There were six results reporting a positive effect of the operator skill on machine productivity. Andersson (1997) observed differences between the productivity of trainees and experienced machine operators working on the same feller-buncher under similar conditions. The less experienced operators lacked knowledge of how to efficiently use the accumulator when bunching trees. Moreover, the inexperienced operators showed difficulties in maneuvering the machines in challenging terrain conditions. A similar effect of the level of operator training was observed by Hillman (2003). Although there are no studies that specifically investigated the operator effect in steep slope harvesting, Amishev and Dyson (2018) noticed lower productivity in winch-assisted operations on a cut block with an average slope of $80 \%$ compared to a cut block with an average slope of $50 \%$. One of the explanations for this observation was the great care and attention required of the machine operator to maintain good machine traction and stability. Since winch-assist operations do not have a long history in the Pacific Northwest, many operators are inexperienced in this technology. The productivity of winch-assisted machines is expected to increase with increasing operator experience (Dyson and Strimbu 2018). Sauder and MacIsaac (2004) observed an increased productivity in both clearcuts and selection cuts after operators gained experience. In a first trial, none of the three studied operators had any experience felling in selection cut operations. As a result, productivity was low compared to a second trial in which the operators were more experienced with the harvesting treatment. In accordance with the previous findings, Meek (1997) stated that a felling technique better suited to the conditions would have increased the efficiency of the operator. Richardson (1989) reported a lack of operator skill contributing to a lower productivity rate of feller-directors. In the study, less skilled operators had more difficulty cutting and maneuvering around unmerchantable trees. The felling technique with these machines is, in general, more advanced and requires additional training compared to feller-buncher operations. Although the effects were not studied directly, Dyson and Strimbu (2018) suspected untrained operators to be the cause for a decreased productivity in winchassisted feller-director operation. When the operating angle of the feller-director was not in lead with the anchor machine, its tractive assistance was decreased, which led to a decreased productivity. Roy and Rittich $(2017 b)$ were not able to provide statistical evidence but suggested that a controlled experiment with equal conditions for every operator would have shown differences in their productivity depending on their experience.

\section{Trail layout}

The layout of skid trails in partial cuts can affect felling machine travel time and productivity. In theory, a narrow system of skid trails in thinning or single-tree selection operations allows the felling machine to harvest the residual strips while staying on the trail. In a wider trail spacing, the machine is required to leave the trail to cut trees before bunching the stems aside the trail (Coup et al. 2008). Three studies aimed to investigate the effects of trail spacing on productivity; however, no significant effect was found. Coup et al. (2008) compared felling activities in an $18.3 \mathrm{~m}$ trail spacing and a $12.2 \mathrm{~m}$ trail spacing system. Fellerbuncher productivity was found to be higher in stands with wider trail spacing. The differences were not statistically significant and were not able to be explained by other variables. Similarly, Meek (1997) reported no significant effect of $33 \mathrm{~m}$ trail spacing compared with a $13 \mathrm{~m}$ trail spacing. Plamondon and Brais (2000) studied a system with fixed skid trails for extraction and the freedom for feller-bunchers to leave these trails for felling on so-called "ghost trails". Machine productivity in operations with ghost trails was compared to conventional operations, in which the same trails were used for felling and extracting the timber. The study concluded that there were no significant differences in productivity between feller-bunchers operating in these two systems. Meek (2006) expected lower feller-buncher productivity due to higher travel and maneuvering time in a $33 \mathrm{~m}$ trail spacing operation compared to a conventional trail spacing. However, the results showed higher productivity in stands with wider trail spacing, for which no explanation was provided.

\section{Trees per felling cycle}

The number of trees per felling cycle is an operational factor that is exclusively influencing the productivity of feller-bunchers. Unlike feller-director heads, most feller-bunchers have the ability to accumulate several trees in one work cycle before bunching them for extraction. An increasing effect of the number of trees per work cycle on productivity was reported in four results. In Andersson and Dyson (2005) and Vitorelo et al. (2011), the cycle time was affected by the number of trees felled per work cycle. An increase of productivity with an increasing number of felled stems per cycle was observed, indicating that felling more stems per cycle at a longer cycle time is more efficient than felling fewer stems at a shorter cycle time (Andersson and Dyson 2005). Andersson and Dyson (2005) found four trees to be the optimum number of felled trees per cycle to achieve maximum productivity in a stand with an average DBH of $19.7 \mathrm{~cm}$. Similar results were obtained by Soman et al. (2019), who showed that feller-buncher productivity was directly proportional to the tree size $(\mathrm{DBH}, \mathrm{cm})$ and the number of trees cut per cycle. However, the optimum number of trees felled per cycle can vary across different stand conditions, silvicultural treatments, and machine specifications. Strandgard et al. (2015) studied feller-buncher productivity for a stand with an average tree volume of $0.22 \mathrm{~m}^{3}$ and found comparably low productivity compared to studies in similar conditions. These unexpected findings were explained by the smaller average number of stems accumulated per cycle (2.9) compared to reference studies. The machine used in the study was assumed to be underpowered, as it had difficulties handling and accumulating more trees per cycle.

\section{Machine maintenance and performance}

The improvement of machine maintenance or performance can influence productivity. Rittich (2017b) reported a positive effect from a hydraulic tune-up on feller-buncher productivity. Several machine parts were checked and adjusted to factory specifications in the tune-up. The adjustments resulted in increased maneuverability of the machine, which contributed to an increased productivity and decreased fuel consumption. In a different study, Rittich (2017a) studied the effect of reducing the revolutions per 
minute of a feller-buncher engine on performance. This reduction had a negative effect on the machine's productivity. Carrier travel speed and stability were mentioned by Richardson (1989) as fellerdirector productivity influencing factors. However, there was no further explanation for this observation.

\section{Anchor set-up and relocation}

The anchor machine plays an important role in winch-assist harvesting operations. Currently, there is no agreement regarding the work cycle definition in productivity studies of such systems. The question arises whether specific tasks related to the anchor machine, such as moving the anchor, should be included in the productive working time of the machine or not. Even though the anchors provide essential support as the felling machine moves across the slope, thereby enabling a safe and productive operation, Leslie and Koszman (2019a) suggest that the relocation of anchors should be non-productive time by strict definition. Meanwhile, Dyson and Strimbu (2018) argue that if defined as productive work time, the two work elements set-up time and anchor relocation have a substantial impact on measured productivity per PMH.

Further, Dyson and Strimbu (2018) found that the angle at which the felling machine travels to the anchor machine had an impact on the felling machine's traction. As a result, the fellerdirector productivity decreased if the machine was not traveling in lead with the anchor machine.

\section{Conclusion}

With its systematic approach, this study allowed the extensive collection of evidence on the factors influencing the productivity of feller-bunchers and feller-directors. The authors acknowledge that due to the language constraint, relevant publications might have been neglected. Nevertheless, because of the scientific methodology followed, conclusions on the results can be drawn. This review shows that among all factors identified as having influence on the productivity of feller-bunchers and feller-directors, piece size is the most studied and most relevant. Despite an increase in cycle time, productivity seems to increase with increasing piece size. Given the mono-directional nature of most productivity functions, there is no upper limit for the effect of increasing piece size. Due to a lack of feller-buncher studies in higher volume and DBH classes, it is vital to investigate whether the productivity increase from piece size is only limited by the size of the feller-head.

Silvicultural treatments can have a significant impact on the feller-buncher productivity. The more machines travel and maneuver, the greater the cycle time, thereby lowering the productivity while other influencing factors remain constant. Selection cuts increase the travel time between trees to be harvested, just as a lower stand density does in clearcuts. Generally, for both feller-bunchers and feller-directors, it can be stated that productivity will decrease in a more complex system with higher demands on the operators' skills. That being said, an experienced operator that is familiar with the silvicultural treatment can still achieve relatively high productivity when compared to a less skilled operator.

This study revealed a lack of productivity research in steep slope harvesting operations. As suggested in previous studies, especially the inclusion of the soil's bearing capacity as a variable affecting productivity on steeper terrain is lacking. Feller-buncher productivity decreases in moderate steep slopes and steep slopes. However, a decrease in productivity on steep slopes was not observed in winch-assist feller-director operations. One of the major drawbacks of in-field observational productivity studies is the fact that individual variables can be difficult to isolate. Different factors might enhance or diminish the influence of others, when simultaneously present. The effect of slope, for example, might be dependent on the soil type and the operator skills (especially in winch-assist operations) to some extent. The piece size-dependent productivity "sweet-spot" might be reached earlier on steep slopes as the handling of larger diameter stems becomes more challenging. A productivity study conducted on a machine simulator could facilitate a controlled environment that allows the isolation of individual factors, such as the ones discussed in this study.

Despite the numerous factors identified as affecting productivity, this study has shown that there are still many factors whose effect on productivity has not been sufficiently studied. Particularly, there has not been enough study on the effects of snow cover on productivity. Snow can affect the traction of the machine's undercarriage and further interfere with the functionality of the felling head. Alternately, the reduced soil impact and lowered travel restrictions provided by snow cover might increase productivity by reducing travel time. To better understand the impact of snow on machine productivity, further studies are required.

Even though Kellogg (1992) stated, "much is known about harvesting productivity and how harvesting and stand variables affect the operational efficiency of mechanized harvesting systems", there is still much that remains unknown. In fact, this study revealed a lack of statistical analysis in the majority of the reviewed results. Although there exist several best practice guidelines that aim to standardize the methodology for time studies, they do not seem to be widely used for feller-buncher and feller-director productivity studies. To compare productivity rates across studies, a standardized study design for productivity measurement is crucial.

Further, an accurate method of tree-size measurement in wholetree harvesting is needed to improve productivity models. As of now, there are no applications for feller-buncher or feller-director that measure the size or number of felled trees. In most of the results in this study, the average volume used to determine productivity was either based on a sample of representative trees or was estimated from cruise data. To better understand the effect of tree size on feller-bunchers and feller-directors and achieve a close to real-time productivity measurement, as it is done in cut-to-length harvesting, technological solutions must become available. Sensors that can be attached to the machines' felling heads can facilitate data collection for the number and size of felled trees. In future research, improved productivity algorithms could be used in benchmarking tools that can accurately predict the productivity of whole-tree harvesting operations. These updated productivity models will further allow the optimization of harvesting operations, help identify bottlenecks, and support the development of best practices.

\section{Competing interests}

The authors declare there are no competing interests.

\section{Funding}

This research was supported by the Office of the Vice President, Research and Innovation at The University of British Columbia, Vancouver, Canada (grant No. 1).

\section{Author contributions}

SL: Conceptualization, Methodology, Validation, Formal analysis, Investigation, Data Curation, Writing - Original Draft, Visualization. OM: Conceptualization, Validation, Writing — Review and Editing. JM: Conceptualization, Methodology, Validation, Writing — Review and Editing.

SG: Writing — Review and Editing.

DR: Conceptualization, Validation, Writing — Review and Editing, Supervision, Funding acquisition.

\section{Data availability}

A small proportion of the results retrieved from the FPInnovations library required a membership to be accessed. All other results were retrieved from the listed libraries with the subscriptions of The 
University of British Columbia or the University of Padua (see "Search for articles" in the Materials and methods section). The data set that was created from the extracted metadata in this study is not available to the public.

\section{Acknowledgements}

The authors would like to acknowledge the financial support for this study from the Office of the Vice President, Research and Innovation at The University of British Columbia, Vancouver, Canada.

\section{References}

Adebayo, A.B., Han, H.-S., and Johnson, L. 2007. Productivity and cost of cutto-length and whole-tree harvesting in a mixed-conifer stand. For. Prod. J. 16(1): 41-48. doi:10.1080/21580103.2020.1712264.

Akay, A.E., Erdas, O., and Sessions, J. 2004. Determining productivity of mechanized harvesting machines. J. Appl. Sci. 4(1): 100-105. doi:10.3923/ jas.2004.100.105.

Alam, M., Acuna, M., and Brown, M. 2013. Self-levelling feller-buncher productivity based on Lidar-derived slope. Croatian J. For. Eng. 34(2): 273-281. Available from http://www.crojfe.com/archive/volume-34-no-2/self-levelling-feller-buncherproductivity-based-on-lidar-derived-slope/.

Alam, M., Strandgard, M., and Brown, M. 2014. Using LiDAR slope estimates to predict the productivity of a self-levelling feller-buncher. Australian Forest Operations Research Alliance. Industry Bulletin, Volume 10. Available from https://research.usc.edu.au/esploro/outputs/workingPaper/Using-LiDAR-slopeestimates-to-predict/99449028002621.

Amishev, D., and Dyson, P. 2018. Falcon Forestry Equipment (FFE) winch-assist harvesting system. No. 39. FPInnovations, Vancouver, B.C., Canada.

Amishev, D., and Evanson, T. 2010. Innovative methods for steep terrain harvesting. In The 43rd International Symposium on Forestry Mechanisation: "Forest Engineering: Meeting the Needs of the Society and the Environment." Edited by C. Kanzian. FORMEC, Vienna. pp. 1-9. Available from https://www.formec.org/images/proceedings/2010/Ab071.pdf.

Amishev, D., Strimbu, V., and Schaare, R. 2017. Mechanized harvesting on steep slopes: short-term evaluation of the E.M.S. tractionline winch-assist system. No. 1. FPInnovations, Vancouver, B.C., Canada.

Andersson, B. 1997. Harvesting coastal second-growth hand- and machinefelled timber. TN-261. Forest Engineering Research Institute of Canada, Vancouver, B.C., Canada.

Andersson, B., and Dyson, P. 2005. Butt damage and machine productivity with various degrees of multiple-tree felling: a case study. No. 18. Forest Engineering Research Institute of Canada, Vancouver, B.C., Canada.

Andersson, B., and Evans, C. 1996. Harvesting overmature aspen stands in central Alberta. SR-112. Forest Engineering Research Institute of Canada, Vancouver, B.C., Canada.

Andersson, B., and Jukes, W. 1995. Harvesting coastal second-growth forests: two case studies. TN-232. Forest Engineering Research Institute of Canada, Vancouver, B.C., Canada.

Axelsson, S.-A. 1998. The Mechanization of logging operations in Sweden and its effect on occupational safety and health. J. For. Eng. 9(2): 25-31. doi:10.1080/08435243.1998.10702715.

Björheden, R. 1991. Basic time concepts for international comparisons of time study Reports. J. For. Eng. 2(2): 33-39. doi:10.1080/08435243.1991.10702626.

Botard, S., Aguilar, F.X., Stelzer, H., Gallagher, T., and Dwyer, J. 2015. Operational costs and sensitivity analyses of an integrated harvest of solid hardwood products and woody biomass: case study in central Missouri. For. Sci. 61(6): 10581067. doi:10.5849/forsci.14-080.

Cadei, A., Mologni, O., Röser, D., Cavalli, R., and Grigolato, S. 2020. Forwarder productivity in salvage logging operations in difficult terrain. Forests, 11(3): 341. doi:10.3390/f11030341.

Conrad, J.L., Chad Bolding, M., Michael Aust, W., Smith, R.L., and Horcher, A. 2013. Harvesting productivity and costs when utilizing energywood from pine plantations of the southern Coastal Plain USA. Biomass Bioenergy, 52: 85-95. doi:10.1016/j.biombioe.2013.02.038.

Cormier, D. 2002. Spot scarification during felling. No.10. Forest Engineering Research Institute of Canada, Vancouver, B.C., Canada.

Coup, C., Benjamin, J., and Wagner, R. 2008. Harvesting biomass to improve low-value beech dominated hardwood stands in Maine. In COFE - Council On Forest Engineering - Conference Proceedings 2008. Council on Forest Engineering. pp. 129-134. Available from https://cofe.org/index.php/meetings/ proceedings/200-2008-addressing-forest-engineering-challenges-of-the-futurecharleston-south-carolina.

Covidence. 2021. Covidence. Available from https://www.covidence.org.

Dodson, E.M., Deboodt, T., and Hudspeth, G. 2006. Production, cost, and soil compaction estimates for two western juniper extraction systems. West. J. Appl. For. 21(4): 185-194. doi:10.1093/wjaf/21.4.185.
Dyson, P., and Boswell, B. 2016. Winch-assisted feller-buncher equipped with a continuous-rotation disc saw: short-term productivity assessment. No 46. FPInnovations, Vancouver, B.C., Canada.

Dyson, P., and Strimbu, V. 2018. Remote operated bulldozer (rob) assisting a feller director: productivity and felling breakage assessment. No. 29. FPInnovations, Vancouver, B.C., Canada.

Elsevier. 2021. Mendeley Desktop. Available from https://www.mendeley.com.

Evanson, T., and Amishev, D. 2010. A steep slope excavator feller buncher. FFR Harvesting Technical Note. Future Forests Research Ltd., Rotorua, New Zealand.

Faasch, R.J., and Patenaude, G. 2012. The economics of short rotation coppice in Germany. Biomass Bioenergy, 45: 27-40. doi:10.1016/j.biombioe.2012. 04.012 .

Gellerstedt, S., and Dahlin, B. 1999. Cut-to-length: the next decade. J. For. Eng. 10(2): 17-24. Available from https://journals.lib.unb.ca/index.php/IJFE/article/ view/30114.

Ghaffariyan, M. 2019. Short review on overview of forest biomass harvesting case studies in Australia. Silva Balcanica, 20(1): 89-96. Available from https:/ silvabalcanica.files.wordpress.com/2020/03/sb_201-2019-089-096.pdf.

Ghaffariyan, M., and Acuna, M. 2012. Evaluating a cut-to-length harvesting system in Tasmania. CRC for Forestry. Bulletin No.23. Available from https:// research.usc.edu.au/discovery/fulldisplay/alma99450224102621/61USC_INST: ResearchRepository.

Ghaffariyan, M.R., Sessions, J., and Brown, M. 2012. Machine productivity and residual harvesting residues associated with a cut-to-length harvest system in southern Tasmania. South. For. 74(4): 229-235. doi:10.2989/20702620. 2012.741770.

Gingras, J.F., and Charette, F. 2017. FPInnovations' Forestry 4.0 Initiative. In 2017 Council on Forest Engineering Annual Meeting. Council on Forest Engineering.

Gingras, J.-F., and Godin, A. 1996. A comparison of feller-bunchers and harvesters for harvesting blowdown timber. TN-244. Forest Engineering Research Institute of Canada, Vancouver, B.C., Canada.

Gingras, J.-F., and Godin, A. 2001. Producing multiple log products: a systems comparison. No. 10. Forest Engineering Research Institute of Canada, Vancouver, B.C., Canada.

Gingras, J.-F., and Soucy, M. 1999. Sorting of multiple products with a cut-tolength system. TN-296. Forest Engineering Research Institute of Canada, Vancouver, B.C., Canada.

Girard, P. 2009. A comparison of the productivity of mechanized clearcutting and selection cuts of hardwood and mixed forests. No. 8. FPInnovationsFERIC, Vancouver, B.C., Canada.

Haddaway, N.R., Collins, A.M., Coughlin, D., and Kirk, S. 2015. The role of Google Scholar in evidence reviews and its applicability to grey literature searching. PLoS One, 10(9): e0138237. doi:10.1371/journal.pone.0138237. PMID: 26379270.

Han, H.S., and Renzie, C. 2001. Snip \& skid: partial cut logging to control mountain pine beetle infestations in British Columbia. In The International Mountain Logging and 11th Pacific Northwest Skyline Symposium. Edited by P. Schiess and F. Krogstad. University of Washington. pp. 96-104. Available from http://depts.washington.edu/sky2001/proceedings/ papers/Han.pdf.

Han, H., Chung, W., She, J., Anderson, N., and Wells, L. 2018. Productivity and costs of two beetle-kill salvage harvesting methods in northern Colorado. Forests, 9(9): 572. doi:10.3390/f9090572.

Harrill, H., and Han, H.-S. 2012. Productivity and cost of integrated harvesting of wood chips and sawlogs in stand conversion operations. Int. J. For. Res. 2012: 893079. doi:10.1155/2012/893079.

Hartley, D.S., and Han, H.-S. 2007. Effects of alternative silvicultural treatments on cable harvesting productivity and cost in western Washington. West. J. Appl. For. 22(3): 204-212. doi:10.1093/wjaf/22.3.204.

Harzing, A.W. 2007. Publish or perish. Available from https://harzing.com/ resources/publish-or-perish.

Heinimann, H.R. 2004. HARVESTING | forest operations under mountainous conditions. In Encyclopedia of Forest Sciences. Edited by J. Burley. Elsevier, Oxford, UK. pp. 279-285.

Hiesl, P., Benjamin, J.G., and Roth, B.E. 2015. Evaluating harvest costs and profit of commercial thinnings in softwood stands in west-central Maine: a case study. For. Chron. 91(2): 150-160. doi:10.5558/tfc2015-026.

Hillman, D. 2001. Productivity of a cable yarder teamed with a fellerbuncher and a grapple skidder. No. 36. Forest Engineering Research Institute of Canada, Vancouver, B.C., Canada.

Hillman, D. 2003. Harvesting with the protection of small merchantable stems: costs and implementation. No. 17. Forest Engineering Research Institute of Canada, Vancouver, B.C., Canada.

Hillman, D. 2004. Comparison of two- and three-machine cut-to-length systems in harvesting small-dimension softwoods. No. 37. Forest Engineering Research Institute of Canada, Vancouver, B.C., Canada.

Hillman, D. 2005. Productivities of various types of harvesting equipment in white birch stands. No. 3. Forest Engineering Research Institute of Canada, Vancouver, B.C., Canada.

Holzfeind, T., Visser, R., Chung, W., Holzleitner, F., and Erber, G. 2020. Development and benefits of winch-assist harvesting. Curr. Forestry Rep. 6(3): 201-209. doi:10.1007/s40725-020-00121-8. 
Kellogg, L., and Brink, M. 1992. Mechanized felling in the Pacific Northwest: existing and future technology. Forest Research Laboratory, Oregon State University, Corvallis, Ore., USA.

Kellogg, L., Bettinger, P., Robe, S., and Steffert, A. 1992. Mechanized Harvesting: a compendium of research. Forest Research Laboratory, Oregon State University, Corvallis, Ore., USA.

Kim, Y., Chung, W., Han, H., and Anderson, N.M. 2017. Effect of downed trees on harvesting productivity and costs in beetle-killed stands. For. Sci. 63(6): 596-605. doi:10.5849/FS-2016-100R3.

Kizha, A.R., and Han, H.-S. 2016. Processing and sorting forest residues: cost, productivity and managerial impacts. Biomass Bioenergy, 93: 97-106. doi:10. 1016/j.biombioe.2016.06.021.

Kosicki, K.T., and Dyson, P.F. 2003. Using mechanized systems to harvest second-growth forests in coastal British Columbia: evaluation of Madill T2200 and Tigercat 860 feller-bunchers. No. 28. Forest Engineering Research Institute of Canada, Vancouver, B.C., Canada.

Kühmaier, M., and Stampfer, K. 2010. Development of a multi-attribute spatial decision support system in selecting timber harvesting systems. Croatian J. For. Eng. 31(2): 75-88. Available from http://www.crojfe.com/archive/volume31-no-2/development-of-a-multi-attribute-spatial-decision-support-systemin-selecting-timber-harvesting-systems/.

Längin, D., Ackerman, P., Krieg, B., Immelmann, A., Potgieter, C., Van Rooyen, J., and Upfold, S. 2010. South African chainsaw safety and operating handbook. Forest Engineering Southern Africa and Institute for Commercial Forestry Research, Scottsville.

Lepage, D., and Meek, P. 2011. Operational trial of the selection cut using the 123 method. FPInnovations-FERIC, Vancouver, B.C., Canada.

Leslie, C., and Koszman, C. 2019a. Assessment of remote operated bulldozer winch-assist in British Columbia's Armstrong region. No. 7. FPInnovations, Vancouver, B.C., Canada.

Leslie, C., and Koszman, C. 2019b. Productivity and utilisation of winchassist machines: case studies in New Zealand and Canada. Report No. H039. Forest Growers Research Ltd., Rotorua, New Zealand.

Long, C., Wang, J., McNeel, J., and Baumgras, J. 2002. Production and cost analysis of a feller-buncher in central Appalachian hardwood forests. In Council on Forest Engineering. Morgantown. pp. 79-83. Available from https://cofe.org/pdfs/COFE_2002.pdf.

MacDonald, A.J. 1999. Harvesting systems and equipment in British Columbia. B.C. Ministry of Forests Forestry Division Services Branch Production Resources, Victoria. Available from https://www.for.gov.bc.ca/hfd/pubs/docs/sil/ sil468.htm.

Magagnotti, N., Spinelli, R., Acuna, M., Bigot, M., Guerra, S., Hartsough, B., et al. 2012. Good practice guidelines for biomass production studies, COST Action FP-0902, WG 2 Operations research and measurement methodologies. CNR IVALSA, Sesto Fiorentino, Italy. Available from https:/|www. researchgate.net/publication/283419641_Good_practice_guidelines_for_biomass_ production_studies_COST_Action_FP-0902_WG_2_Operations_research_and_ measurement_methodologies.

Marchi, E., Chung, W., Visser, R., Abbas, D., Nordfjell, T., Mederski, P.S., et al. 2018. Sustainable Forest Operations (SFO): a new paradigm in a changing world and climate. Sci. Total Environ. 634: 1385-1397. doi:10.1016/j. scitotenv.2018.04.084. PMID:29710638.

McMorland, B. 1985. Production of mechanical felling equipment on coastal B.C.: Timbco Feller Buncher with RotoSaw Head. TN-85. Forest Engineering Research Institute of Canada, Vancouver, B.C., Canada.

McMorland, B. 2002. Restricted to FERIC Members and Partners INTERFACE Productivity Data from Western Canada: Feller-bunchers II. PR-6. Forest Engineering Research Institute of Canada, Vancouver, B.C., Canada.

McMorland, B. 2008. Productivity data from western Canada: bunchers III. PR-12. FPInnovations-FERIC, Vancouver, B.C., Canada.

Mcnamara, R., Meek, P., and Alvarez, É. 1999. strategies for reducing the cost of mechanized selection harvesting in hardwood forests. TN298. Forest Engineering Research Institute of Canada, Vancouver, B.C., Canada.

Meek, P. 1997. Mechanized selection cutting in hardwoods with a TIMBCO T-445. TN-265. Forest Engineering Research Institute of Canada, Vancouver, B.C., Canada.

Meek, P. 2006. An implementation guide for mechanized single-tree selection using 33-m trail spacing. No. 5. Forest Engineering Research Institute of Canada, Vancouver, B.C., Canada.

Meek, P. 2013. Efficiency of the 1-2-3 selection cutting method in hardwood forests. No. 2. FPInnovations, Vancouver, B.C., Canada.

Meek, P., and Légère, G. 1998. Trials of two harvesting systems for shelterwood cutting in softwood stands. TN-269. Forest Engineering Research Institute of Canada, Vancouver, B.C., Canada.

Moher, D., Liberati, A., Tetzlaff, J., and Altman, D.G. The PRISMA Group. 2009. Preferred Reporting Items for Systematic Reviews and Meta-Analyses: The PRISMA Statement. PLoS Med. 6(7): e1000097. doi:10.1371/journal.pmed. 1000097. PMID:19621072.

Nishio, G. 2010. Harvesting mountain pine beetle-killed pine while protecting the secondary structure: a comparison of partial harvesting and clearcutting methods. No. 1. FPInnovations, Vancouver, B.C., Canada.
Ovaskainen, H., Palander, T., Lasse, T., Hirvonen, H., and Ronkainen, P. 2011. Productivity of different working techniques in thinning and clear cutting in a harvester simulator. Baltic For. 17: 288-298. Available from https://www.researchgate.net/publication/261366042_Productivity_of_Different_ Working_Techniques_in_Thinning_and_Clear_Cutting_in_a_Harvester_Simulator.

Pan, P., and McDonald, T. 2019. Tree size estimation from a feller-buncher's cutting sound. Comput. Electron. Agric. 159: 50-58. doi:10.1016/j.compag.2019.02.021.

Parajuli, M., Hiesl, P., Smidt, M., and Mitchell, D. 2020. Factors influencing productivity and cost in the whole-tree harvesting system. Clemson (SC): Clemson Cooperative Extension, Land-Grant Press by Clemson Extension (LGP 1079): 8. Available from https://lgpress.clemson.edu/publication/factorsinfluencing-productivity-and-cost-in-the-whole-tree-harvesting-system/.

Phillips, E. 1997. Comparison of conventional and mechanical harvesting for the Prince Albert Model Forest. SR-121. Forest Engineering Research Institute of Canada, Vancouver, B.C., Canada.

Phillips, E. 2004. Harvesting to emulate natural disturbance: EMEND harvesting costs and productivity. No. 36. Forest Engineering Research Institute of Canada, Vancouver, B.C., Canada.

Phillips, E. 2010. Cost and productivity of alternative harvesting in BC's interior wet-belt designed to maintain caribou habitat. No. 27. FPInnovations-FERIC, Vancouver, B.C., Canada.

Plamondon, J., and Brais, S. 2000. Effects of ghost trails on soils and advanced regeneration. No. 34. Forest Engineering Research Institute of Canada, Vancouver, B.C., Canada.

Richardson, R. 1989. Evaluation of the Denis D-55 Directional Felling Head. TN-128. Forest Engineering Research Institute of Canada, Vancouver, B.C., Canada.

Riopel, M., Bégin, J., and Gingras, J.-F. 2000. Harvesting with protection of small merchantable stems: an option for the boreal forest. No. 17. Forest Engineering Research Institute of Canada, Vancouver, B.C., Canada.

Rittich, C. 2017a. Effect of reduced engine RPM on feller buncher performance. IN-17. FPInnovations, Vancouver, B.C., Canada.

Rittich, C. 2017b. Hydraulic tune-up to improve feller buncher energy intensity. IN-16. FPInnovations, Vancouver, B.C., Canada.

Rowlett, R. 2018. How many? A dictionary of units of measurement. Available from https://www.ibiblio.org/units/ [accessed 15 March 2021].

Roy, V., and Rittich, C. 2017a. Benchmarking and energy intensity profiling. No. 12. FPInnovations, Vancouver, B.C., Canada.

Roy, V., and Rittich, C. 2017b. Long-term benchmark study of fuel consumption by feller-bunchers. No. 49. FPInnovations, Vancouver, B.C., Canada.

Sambo, S. 2003. Using a group selection silvicultural system to maintain caribou habitat in southern British Columbia. No. 4. Forest Engineering Research Institute of Canada, Vancouver, B.C., Canada.

Sauder, E., and MacIsaac, D. 2004. Using alternative harvesting techniques to protect the boreal mixedwood understorey: evaluation of harvesting productivity and costs. No. 12. Forest Engineering Research Institute of Canada, Vancouver, B.C., Canada.

She, J., Chung, W., and Kim, D. 2018. Discrete-event simulation of ground-based timber harvesting operations. Forests, 9(11): 683. doi:10.3390/f9110683.

Silversides, C.R., and Sundberg, B. 2013. Operational efficiency in forestry: Vol. 2: Practice. Springer Science \& Business Media, Berlin, Germany. pp. 68-70.

Soman, H., Kizha, A.R., and Roth, B.E. 2019. Impacts of silvicultural prescriptions and implementation of best management practices on timber harvesting costs. Int. J. For. Eng. 30(1): 14-25. doi:10.1080/14942119.2019.1562691.

Soman, H., Kizha, A.R., Muñoz Delgado, B., Kenefic, L.S., and Kanoti, K. 2020. Production economics: comparing hybrid tree-length with whole-tree harvesting methods. Forestry, 93(3): 389-400. doi:10.1093/forestry/cpz065.

Spinelli, R., and Magagnotti, N. 2011. The effects of introducing modern technology on the financial, labour and energy performance of forest operations in the Italian Alps. For. Policy Econ. 13(7): 520-524. doi:10.1016/j.forpol.2011. 06.009 .

Spinelli, R., Lombardini, C., and Magagnotti, N. 2013. Salvaging windthrown trees with animal and machine systems in protected areas. Ecol. Eng. 53: 61-67. doi:10.1016/j.ecoleng.2012.12.012.

Spinelli, R., Lombardini, C., and Magagnotti, N. 2014. The effect of mechanization level and harvesting system on thinning cost and impact under Mediterranean forest conditions. Silva Fenn. 42(1): 1003. doi:10.14214/ sf.1003.

Strandgard, M., and Mitchell, R. 2010. Benchmarking feller-buncher productivity in Western Australian blue gum plantations. CRC for Forestry. Harvesting and Operations Bulletin 12. Available from https://research.usc.edu.au/discovery/ fulldisplay/alma99448819402621/61USC_INST:ResearchRepository.

Strandgard, M., Walsh, D., and Mitchell, R. 2015. Productivity and cost of wholetree harvesting without debarking in a Eucalyptus nitens plantation in Tasmania, Australia. South. For. 77(3): 173-178. doi:10.2989/20702620.2014.1001669.

Thompson, J. 2003. Productivity of a tree length harvesting system thinning Ponderosa pine in northern Arizona. Council on Forest Engineering, Morgantown, West Virginia, USA

Visser, R. 2009. Effect of piece size on felling machine productivity. Harvesting Technical Note. Vol. 2, No. 9.

Visser, R., and Stampfer, K. 2015. Expanding ground-based harvesting onto steep terrain: a review. Croatian J. For. Eng. 36(2): 321-331. Available from http://www.crojfe.com/site/assets/files/4023/visser.pdf. 
Visser, R., Raymond, K., and Harrill, H. 2014. Developing fully mechanised steep terrain harvesting operations. Edited by C. Kanzian. FORMEC. Available from https://www.formec.org/images/proceedings/2014/a23.pdf.

Vitorelo, B., Han, H.-S., and Elliot, W. 2011. Productivity and cost of integrated harvesting for fuel reduction thinning in mixed-conifer forest. For. Prod. J. 61(8): 664-674. doi:10.13073/0015-7473-61.8.664.

Watson, W.F., Stokes, B.J., Hartsough, B.R., and Haglund, S.A. 1995. Implementing health improvement cuttings in conifer stands in southwestern highlands. In Sustainability, Forest Health \& Meeting the Nation's Needs for Wood Products. Council on Forest Engineering. pp. 144-151. Available from https://cofe.org/pdfs/COFE 1995.pdf.

Williams, W.A. 1990. Performance of circular saw felling head in hardwood conditions. TN-156. Forest Engineering Research Institute of Canada, Vancouver, B.C., Canada. 